\title{
Creativity of Pre-service Teachers in Problem Posing
}

\author{
Wajeeh Daher ${ }^{1,2^{*}}$, Ahlam Anabousy ${ }^{2}$ \\ ${ }^{1}$ An-Najah National University, Nablus, West Bank, PALESTINE \\ ${ }^{2}$ Al-Qasemi Academic College of Education, Baqa El-Garbiah, ISRAEL \\ Received 4 April 2017 - Revised 15 April 2018 - Accepted 21 April 2018
}

\begin{abstract}
Problem posing and technology are attracting the attention of mathematics educators because of their potential to affect positively many aspects of students' learning. Little research has been done on the relationship between technology and mathematical creativity. The present study investigates this issue in the context of problem posing, in the presence and absence of a strategy for problem posing (the "what-if-not" strategy). Participants were pre-service mathematics teachers. The research was conducted during the academic year 2013-2014. Participants were randomly divided into four groups of 19 to 21 participants and who differed in their use of technology and of the what-if-not strategy. The participants who used technology used the Paper Pools applet. The data was collected from the participants' posing problems on a specific mathematics situation; the Paper Pool situation. The data analysis was done using SPSS 18.0. The research findings indicate that the combination of technology and the what-if-not strategy has a positive and significant effect on the three components of participants' creativity: fluency, flexibility and originality. Separately, both technology and the what-if-not strategy had a positive and significant effect on participants' fluency and flexibility related to problem types, but not related to strategy types. The findings also indicate that the originality of participants who worked without technology but with the what-if-not strategy was significantly lower than that of participants who worked with technology, whether with or without the what-if-not strategy. Thus, results indicated that technology is more effective than the what-if-not strategy in encouraging originality in problem posing. We recommend the use of technology together with the what-if-not strategy to enhance pre-service teachers' mathematical thinking, because this combination makes available for student's learning multiple agencies required for his/her creative acts.
\end{abstract}

Keywords: creativity, problem posing, pre-service teachers, technology, what-if-not strategy

\section{INTRODUCTION}

The main focus of the present paper is on problem posing as a creative experience of pre-service teachers and how this creative experience is affected by the use of tools, such as what-if-not strategy and technology. Researchers (e.g., Bonotto, 2013) point at problem posing as a form of structured "rich contexts" creative activity (Freudenthal, 1991) in which students can be engaged with the support of artifacts and human interactions (English, 2009).This description of problem posing makes it necessary to examine the influence of tools, namely technology and whatif-not strategy on students' creativity in problem posing tasks. The current research intends to do so, when preservice teachers pose mathematical problems related to the Paper Pool task and which will be described in the methodology section.

(C) 2018 by the authors; licensee Modestum Ltd., UK. This article is an open access article distributed under the terms and conditions of the Creative Commons Attribution License (http://creativecommons.org/licenses/by/4.0/). $\square$ daherwajeeh@gmail.com (Correspondence) $\square$ ahlamanabosy@gmail.com 


\section{Contribution of this paper to the literature}

- It investigates the creativity of pre-service teachers in in problem posing in four environments that differ from each other in the use of technology and what-if-not strategy.

- It uses mainly a quantitative methodology but it combines with it a qualitative methodology to find the categories of the participants' flexibility in problem types and problem strategies, as well as of the participants' originality.

\section{Problem Posing}

Problem posing and solving are two main components of teaching and learning mathematics (Akay \& Boz, 2009; Leung, 2013; NCTM, 2000). Problem posing helps advance the development of mathematical ability and autonomy of learning (Kilpatrick, 1987; Mamona-Downs \& Downs, 2005). Mathematics educators are interested in problem posing because of its capability to affect positively the problem-solving abilities of students, as well as other features of student learning, such as high order thinking including creative and critical thinking. Problemposing tasks require the composition of new problems by changing the given conditions of the original one. The composition of new mathematical problems are expected to help investigate a given or a new situation (Silver, 1994).

Stoyanova (1998) categorised problem-posing experiences as: free, semi-structured, and structured. Free problem posing experiences involve unrestricted posing of problems; semi-structured problem posing experiences involve students' engagement with writing problems that are similar to the given or based on a specific feature. Structured problem posing experiences involve posing problems by restating an already solved problem or by modifying the conditions of a given problem. In the current study, structured problem-posing situations were used. These situations were related to the Paper Pool task. Utilizing the mathematical situation, the participants posed problems using one or both of the following tools: technology and what-if-not strategy.

The what-if-not strategy was introduced by Brown and Walter $(1969,1990)$ as a tool to extend the problem situation. It is based on generating new and interested problems through modifying the givens of an original problem. Teachers who implement the what-if-not strategy can move away from rigid teaching that consists of only one right way to a problem. Through this strategy, students can discuss different ideas and consider the different meanings of the problem (Brown \& Walter, 1993). Carrying out this strategy, students begin with the examination of the problem. Doing that, they produce a list of the features of the problem. This producing of the list of features is followed, for each feature, by asking the what-if-not question and proposing alternatives to the original problem. Afterwards, the students utilize the alternatives to formulate new problems.

Studies that investigated problem posing using the what-if-not strategy reported on the type of problems posed by participants, on the effect of its use on the problem-posing activity of students, and on the students' difficulties in problem posing. For example, English (1998) analysed processes that eight-year-old students performed when they were asked to pose problems using the what-if-not strategy in formal or non-formal contexts. English found that the children offered different problems by changing the conditions of non-formal problems, but had difficulty varying the conditions of formal ones. Lavy and Bershadsky (2003) reported on pre-service teachers use of the what-if-not strategy to generate problems based on a complicated space geometry task. The results indicated that pre-service teachers posed a wide range of problems, including some in which they replaced a numeric value with another, and including problems that engaged proof. The problems they posed shed light on some phenomena, but lacked formal generalization. Kilic (2013) investigated the problems that pre-service primary teachers posed on fractions. Kilic found that the participants produced primarily story problems, with some non-story problems or/and irrelevant ones.

\section{Technology in problem posing}

Technology has the potential to make problem-posing richer, because it can efficiently take care of the computing and graphing and all other technical work (e.g., Lavy \& Shriki, 2010). Specifically, the interface of the tool facilitates the procedures used by the users, so it impacts positively their understanding (Christou, 2005). Furthermore, the dragging functionality of the software grants students the potentiality of reasoning visually and generalizing problems (Sinclair, 2004). In other situations, technology helps students verify the validity of the new situation (Lavy \& Shriki, 2010).

Abramovich and Cho (2015) investigated the use of graphing software, as a tool for reciprocal problem posing. They found that this tool was effective for posing advanced problems about algebraic equations that include parameters. Moreover, Beal and Cohen (2012) found that middle school students were able to generate mathematics 
and science problems using a web-based sharing system with content-authoring capabilities. These results make it possible that technology contributes positively to students' problem posing.

Of special interest, concerning problem posing, is its positive effect on students' creativity (Silver, 1997; Silver \& Cai, 2005; Singer, Ellerton, \& Cai, 2013). Creativity as an aspect of mathematics learning has been a rising topic of mathematics education research in the past two decades. In the present study, we examine the impact of technology and a problem-posing strategy on mathematical creativity of pre-service teachers.

\section{Creativity in Mathematics Education}

In mathematics education, only lately researchers have shown interest in creativity research (Leikin \& PittaPantazi, 2013; Sriraman, Haavold \& Lee, 2013). This interest has risen due to different factors as the call of mathematics education researchers (e.g., Haylock, 1987). Another factor is the functions of creativity in the 21st century by itself and because it is interconnected with other 21st century skills (Pásztor, Molnár, \& Csapó, 2015). specifically, problem solving and posing often requires creative ideas. This is especially true for mathematical problem posing, where emergence of new and intriguing problems is enriched in a creative environment.

In spite of the attempt of various researchers to define mathematical creativity, no proposed definition has been universally accepted (Mann, 2006). The definitions of creativity given by the different researchers can be put into two categories: those concerned with the final product and those concerned with the process (James, LedermanGerard, \& Vagt-Traore, 2004). Sternberg and Lubart (1999), who adopt the point of view of the final product, describe it as the ability to produce an unexpected work. Researchers who define creativity as a process describe it as the capability to think in a conceptual way. The current article is based on a definition of creativity as a process, which involves three components: fluency, flexibility, and originality (Guilford, 1950, 1975; Torrance, 1966). Our adoption of fluency, flexibility and originality for studying the creativity of pre-service teachers in a problem posing context is also supported by Silver (1997) who claimed the three components are established within the studying of creativity. These claims are stressed again by Sriraman, Haavold, and Lee (2013) who argue that varying combinations of the three components have been used to study mathematical creativity.

In the current research, fluency is related to the number of correct questions that a student produces for a problem. Flexibility is related to the number of question types proposed for a problem. Flexibility is also related to the number of problem-posing strategies that a student has implemented. Originality is related to the number of problems posed that no other person or very few proposed (Leikin, Koichu, \& Berman, 2009; Torrance, 1969, 1974).

Studies on mathematics creativity report its positive effect on student learning (Lai, 2011; Mann, 2006), suggesting that creativity tasks are highly effective in the mathematics classroom. At the same time, Sriraman (2005) argues that nurturing creativity is not a strategy usually implemented by teachers. It is therefore necessary to introduce pre-service teachers to creativity during their study as mathematics teachers. This is especially true when this introduction is accompanied by tools, such as what-if-not strategy and technology, which could enhance the creative work of these pre-service teachers.

\section{Technology in creativity}

Researchers (Hoyles, 2001; Liekin, 2011; Yerushalmy, 2009) point out that technological tools can enhance the mathematical creativity of students and sustain the attempts of teachers to escalate the mathematical inquiry of students. Specifically, Yerushalmy (2009) argues that technology supports students' cognitive processes, as questioning, conjecturing and exploration, which stimulate their mathematical creativity.

Two disagreeing views populate the literature about the relationship between creativity and technology (Clements, 1995). The first claims technology develops merely mechanistic and uncreative thinking, while the second claims that technology develops creativity. The latter view is consistent with the claim of the National Advisory Committee on Creative and Cultural Education (NACCCE, 1999) about the role of technology. This argument claims that technology assists students in finding new ways of creativity. This argument is consistent with the results of empirical studies that have pointed at technological environments as enhancing students' creative capabilities (e.g., Dunham \& Dick, 1994; Subhi, 1999).

Examining mathematical creativity in technological contexts, some studies have taken a close look at the interactive whiteboard environment (Behzadi \& Manuchehri, 2013; Sophocleous \& Pitta-Pantazi, 2011; Wood \& Ashfield, 2008). The results of these studies emphasize the positive effect of technology on students' mathematical activity, reporting that the technological tool offers students opportunities to imagine, synthesize, and elaborate, in other words, to be creative. By contrast, Wood and Ashfield (2008) pointed at the teacher's skill and professional knowledge as mediating the interaction between students and technology and as facilitating the growth of students' creative answers in the presence of technology. Both arguments support the call to introduce creativity, especially 
with technology, into the curriculum of pre-service teachers. The present research relies on work carried out on creativity in problem-posing tasks with and without technology.

\section{Creativity in Problem Posing}

Voica and Singer (2013) argue that there is no agreement among researchers of mathematics education regarding the relationship between creativity and problem posing, where some of them claim that this link is rather strong, while others claim that problem posing has the potentiality to enrich creativity. For example, Haylock (1987) considers problem posing as a creative ability. On the other side, Silver (1994) commented that a general relationship between problem posing and creativity remains to be demonstrated. Furthermore, cognitive flexibility in the modification of a problem indicates mathematical creativity (Voica \& Singer, 2013).

We describe in detail two studies related to the present one, as they reported students' and teachers' problem posing for the same task: "the Paper Pool". In the first study, by Silver, Mamona-Downs, Leung, and Kenny (1996), the researchers investigated problem posing among middle school teachers and secondary school pre-service teachers. Participants were asked to pose mathematical problems either individually or in pairs-before, during, or after the solution of a problem that was part of the paper pool task. The authors examined the types of problems posed and the cognitive processes used in the problem posing, as well as the differences between problems posed in the course of the phases of student work: before solving the task and during or after solving it. Results showed that the participants posed a large number of reasonable problems during the phases. Participants posed problems in two ways: keeping the conditions of a problem and manipulating these conditions. Participants' experience in solving the problem affected their problem posing. Finally, participants posed also problems that they could not solve.

Kontorovich, Koichu, Leikin, and Berman (2011), who also examined students' work with the paper pool activity, investigated the problem posing by high-achieving secondary school students, and described their fluency, flexibility, originality, and aptness. The authors differentiated between three problem-posing strategies: (a) accepting the givens as they are; (b) varying the givens (table dimensions, starting point of the ball, the initial angle of the ball, and the number of balls); and (c) introducing new types of givens.

The present study investigates pre-service teachers' creativity in problem posing in the Paper Pool context in four environments differing in the use of technology and what-if-not strategy.

\section{Research Rationale and Goals}

Lavy and Bershadsky (2003) argue that developing mathematical problem-posing skills is especially important for the teachers of mathematics because integrating problem-posing activities in the mathematics class facilitates the assessment of their students' mathematical knowledge. According to this approach, it is required that problemposing tasks be part of the preparation of pre-service mathematics teachers. At the same time, researchers indicated that addressing creativity conceptions in pre-service teachers' preparation would encourage them to foster creativity in their students (Bolden, Harries, \& Newton, 2010). Regarding the activity of problem posing by preservice teachers and by students, researchers paid attention to the use of the what-if-not strategy. Silver (1997) has claimed that problem-posing tasks encourage student creativity, and that using a what-if-not strategy encourages student flexibility.

Technology, on its part, can also support creativity (Buteau, 2008) and even stimulate mathematical creativity for all levels of students (Yerushalmy, 2009). Previous research has studied mainly the contribution of technology alone or what-if-not strategy alone to creativity tasks. The present study examines the contribution of each one of them and their combination in creativity in the problem posing setting.

\section{Research Questions}

1. Does the use of different tools (technology and what-if-not strategy) result in significant differences in preservices teachers' creativity in mathematical problem posing, in each research group, before and after the use of these tools?

2. Does the use of different tools (technology and what-if-not strategy) in problem posing result in significant differences in creativity among the research groups according to the use of different combinations of the tools? 
Table 1. Cross-tabulation of use of technology and of the what-if-not strategy

\begin{tabular}{ccccc}
\hline & & \multicolumn{2}{c}{ Technology } & \multirow{2}{*}{ Total } \\
\cline { 2 - 5 } & & Without technology & With technology & \\
\hline \multirow{2}{*}{$\begin{array}{c}\text { What-if-not } \\
\text { strategy }\end{array}$} & Without what-if-not & 21 & 19 & 40 \\
\cline { 2 - 5 } Total & With what-if-not & 20 & 19 & 39 \\
\hline
\end{tabular}

\section{METHOD}

\section{Research Settings, Participants and Design}

Participants were pre-service mathematics teachers. The research was carried out during the academic year 2013-2014. Participants were randomly divided into four groups that differed in their use of tools (what-if-not strategy and technology). Two of the groups, after being introduced to the what-if-not strategy, were requested to work with the Paper Pool task using it. One of the previous two groups was introduced to technology too; specifically to a Java applet, so that the members of this group worked on the task using the combination of the tools - what-if-not strategy and technology. The third research group was introduced to technology alone, as previously mentioned a Java applet, so this group members posed problems on the Paper Pool task using this applet. The fourth research group worked without using any of the tools. Table 1 shows the frequency of participants in each of the research groups. All the research participants had not used the java applet or what-ifnot strategy before the experiment.

The participants who were introduced to a tool, whether what-if-not strategy or technology, did that in two lectures, each of two hours, where in the first lecture they were introduced to the techniques and options of the tool, while in the second lecture they posed problems with the tool, where the problems were not on the Paper Pool situation.

The participants in each one of the four groups performed the activity twice, once before the experiment, where all of them posed problems without technology and without what-if-not strategy. The participants performed the activity again after two weeks in which part of them were introduced to the tools. Furthermore, the participants in all groups had one hour to perform the task. They worked individually, in contrast with Kontorovich et al. (2011). Participants in the two research groups, who utilized technology, worked with the Paper Pool Applet ${ }^{1}$. The same teacher, who was the second author of the paper, worked with the four groups and tried not to interfere with the pre-service teachers' work, for example not to give feedback on the correctness of the problems posed by a student in any of the groups.

Statistical computations using ANOVA indicated that the mean score of the participants in the four groups before the experiment did not differ significantly regarding the four components of creativity. These results were $\mathrm{F}(3,75)=.55, \mathrm{p}=.65$ for fluency; $\mathrm{F}(3,75)=.12, \mathrm{p}=.95$ for flexibility of problem types; $\mathrm{F}(3,75)=.16, \mathrm{p}=.92$ for flexibility of strategies; and $\mathrm{F}(3,75)=.03, \mathrm{p}=.99$ for originality.

\section{Task}

The task in the current research was used in a study by Silver et al. (1996), and it was used also by others as Kontorovich et al. (2011) or Koichu and Kontorovich (2013). We chose this task because it is easily accessed to learners as it needs elementary mathematical knowledge and simultaneously can motivated the generation of stimulating problems (Koichu \& Kontorovich, 2013; Silver et al., 1996). Furthermore, this task is appropriate for students' mathematical work in different environments, whether they include technology or not. Specifically for the current research, an applet from NCTM site was adopted for the participants who use technology. Below is the text of the task.

Imagine billiard tables as the table shown below. Assume that a ball is shot at a $45^{\circ}$ angle from the lower left corner A of the table. On hitting a side of the table, the ball bounces off at a $45^{\circ}$ angle. In the case of Table 1 below, the ball moves on a $4 \times 6$ table and ends up in pocket B after hitting the sides 3 times. In the case of Table 2 below, the ball moves on a $2 \times 4$ table and ends up in pocket $\mathrm{D}$ after hitting the side once. In each of the tables below, the ball hits the sides several times and finally lands in a corner pocket.

\footnotetext{
${ }^{1}$ At http:/ / illuminations.nctm.org/ Activity.aspx?id=4219
} 
Table 2. The number of mathematical solvable problems posed by each of the research groups

\begin{tabular}{llcc}
\hline Group & $\mathbf{N}$ & Number of problems-before & Number of problems-after \\
\hline Without technology, without what-if-not & 21 & 95 & 97 \\
\hline Without technology, with what-if-not & 20 & 83 & 163 \\
\hline With technology, without what-if-not & 19 & 81 & 158 \\
\hline With technology, with what-if-not & 19 & 83 & 277 \\
\hline
\end{tabular}

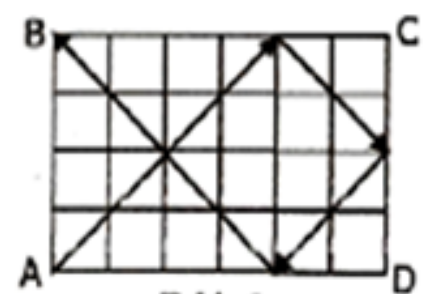

Table 1

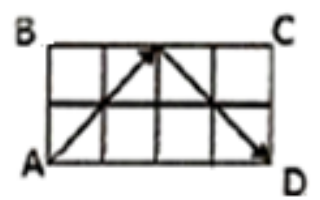

Table 2

Pose as many interesting mathematical problems on this situation as you can.

\section{Collection and Analysis of Data}

We excluded all the problems that were not mathematical or were not solvable. In this way, we excluded the problem "what happens if the table's colour is changed?" for was considered not mathematical.

Fluency in problem posing was determined based on the number of mathematical problems that a student raised and that fitted the requirement of the given task. To compute fluency in the context of the Pool Paper task, we considered every problem posed by the student, checking whether it satisfied two conditions: it was a mathematical problem and it was solvable. We added one point to the student's fluency for every problem posed that satisfied both conditions. The current research is interested in two types of flexibility for students: problem types and posing strategies. We computed the two types of flexibility by counting the number of problem types and the number of problem strategies respectively. The originality score of the participants was computed by counting the number of problems that were not suggested by any of the other participants. The method followed in the current research for analysing the three components of creativity in the context of problem posing agrees with Kontorovich et al. (2011). Using this method, all participants' answers were coded independently by the two researchers. We used Cohen's kappa to measure the agreement between the two raters (Cohen, 1960). Interrater reliability for fluency component was $92.8 \%$, for flexibility component of problem types $89.1 \%$, for flexibility component of strategies $88.8 \%$, and for originality component $92.6 \%$. The high agreement percentages between the two raters suggest that this agreement is good, and therefore, this reliability is satisfactory for each of the components of creativity.

It should be noted that studies in mathematical creativity use different and similar methods to compute the three components of creativity (fluency, flexibility and originality). Generally, researchers, as Leikin and Lev (2013) suggest computing fluency by counting the number of given problems/solutions. Methods of computing flexibility vary. Leikin and Lev (2013) suggest a specific method to compute flexibility (giving 10 points for different problem/solution categories, 1 point for a problem/solution that belongs to a previous category, but has a clear minor distinction from the other problems/solutions previously considered, and 0.1 point for a problem/solution that is almost identical with a previous problem/solution). To compute originality, Leikin and Lev (2013) suggest a relative method, in which a student's problem/solution is compared to the rest of students' problems/solutions, and the unconventional problem/solution is given 10, the partly unconventional problem/solution is given 1, while the conventional solution is given 0.1. On the other hand, Shriki (2013) suggests methods to compute fluency and flexibility that are similar to the methods that the present research uses. At the same time, to compute originality, she suggests a relative method, giving points only to students who gave problems/solutions that only third of the students suggested. We follow Kontorovich et al. (2011) in computing students' fluency, flexibility and originality, for the present research studies the same mathematical situation that they studied (see above for detailed description).

We used paired-sample t-test for investigating the significance of the score difference between the post-test and the pre-test of each of the three creativity components. In addition, we used an ANCOVA test to investigate the significance of the score differences between the creativity of the four groups as a result of using the tools. When the ANCOVA test yielded a significant $\mathrm{F}$, we performed the post hoc test. 
Table 3. Means and standard deviations of participants' fluency in the four groups

\begin{tabular}{|c|c|c|c|c|c|c|c|}
\hline Group & $\mathbf{N}$ & $\begin{array}{c}\text { Before experiment } \\
\text { M (SD) }\end{array}$ & $\begin{array}{c}\text { After experiment } \\
\text { M (SD) }\end{array}$ & $\begin{array}{c}95 \% \mathrm{Cl} \text { for Mean } \\
\text { Difference }\end{array}$ & t value & Sig. & df \\
\hline $\begin{array}{l}\text { Without technology, without } \\
\text { what-if-not }\end{array}$ & 21 & $\begin{array}{c}4.52 \\
(0.74) \\
\end{array}$ & $\begin{array}{c}4.62 \\
(0.81) \\
\end{array}$ & $-0.63,0.43$ & -0.39 & 0.70 & 20 \\
\hline $\begin{array}{l}\text { Without technology, with } \\
\text { what-if-not }\end{array}$ & 20 & $\begin{array}{c}4.15 \\
(0.78) \\
\end{array}$ & $\begin{array}{c}8.15 \\
(2.39) \\
\end{array}$ & $-5.23,-2.76$ & -6.77 & 0.00 & 19 \\
\hline $\begin{array}{l}\text { With technology, without } \\
\text { what-if-not }\end{array}$ & 19 & $\begin{array}{c}4.24 \\
(0.81) \\
\end{array}$ & $\begin{array}{c}8.32 \\
(2.38) \\
\end{array}$ & $-5.52,-2.64$ & -5.97 & 0.00 & 18 \\
\hline $\begin{array}{l}\text { With technology, with what- } \\
\text { if-not }\end{array}$ & 19 & $\begin{array}{c}4.35 \\
(0.85)\end{array}$ & $\begin{array}{l}14.58 \\
(3.31)\end{array}$ & $-11.85,-8.61$ & -13.28 & 0.00 & 18 \\
\hline
\end{tabular}

\section{RESULTS}

\section{Responses (Problems) Posed by the Participating Pre-service Teachers}

Table 2 shows the number of mathematical solvable problems posed by each of the four groups that participated in the research before and after the experiment.

Table 2 shows that before the experiment, all the groups posed relatively the same number of problems, but after the experiment the group who used the combination of the tools posed relatively more problems than each of the other three groups.

We will next answer the two research questions. The first research question asked whether the use of different tools results in significant differences in pre-services teachers' creativity in problem posing, in each research group, before and after the use of these tools. Below we answer this question for each creativity component.

\section{Fluency in Problem Posing Before and After the Use of Tools}

As noted above, fluency in problem posing denotes the number of solvable mathematical problems posed by each student. Below are some examples from the posed problems, chosen randomly from problems that ask about the pocket in which the ball falls:

In which pocket does the ball fall in a table of $5 \times 6$ ? In which pocket does the ball fall in a table of $q \times p$ ? In which pocket does the ball fall in a table of $\mathrm{q} \times(\mathrm{q}+1)$ ?

Table 3 presents the scores means and standard deviations of participants' fluency in the four participating groups before and after the experiment, as well as pair-sample t-value that compares the two means of each group.

The results of the paired-sample t-test pointed out that there was a significant difference between the mean scores of fluency before and after the experiment in the three experiment groups, but no significant difference was obtained for the control group $(\mathrm{p}=0.70)$.

\section{Flexibility in Problem Posing Before and After the Use of Tools}

We computed flexibility in two ways: calculating the number of different types of problems posed by a participant, and calculating the number of different strategies used in posing the problems.

\section{Flexibility-related-to-problems before and after the use of tools}

As to participants' flexibility-related-to-problems, we found that the participants posed ten types of problems: about the ball's path, about the hits' number, about the angle, about the ball's speed, about the pocket in which the ball falls, about the balls' number, about the table dimensions, about the pockets' number, about two of the above issues, and about three of the above issues. Below are some examples of the posed problems, chosen randomly from all the categories. The problems were posed by the group that combined the two tools, in which all the problem types appeared.

What is the path of the ball if it begins from pocket $C$ ? What is the highest number of hits until the ball falls into a pocket? What is the angle that we need to use for the ball for it to fall into pocket B? What happens three balls are thrown? What is the number of balls if the speed of the ball increases? What are the dimensions of the table if the number of hits is five? How should the ball be launched in Table $\mathbf{1}$ and Table $\mathbf{2}$ in order for it to fall in pocket B? What path does the ball have if the number of pockets is eight? Describe the relationship between the measure of 
Table 4. Means and standard deviations of participants' flexibility with regard to types of problems in the four groups

\begin{tabular}{|c|c|c|c|c|c|c|c|}
\hline Group & $\mathbf{N}$ & $\begin{array}{c}\text { Before experiment } \\
\text { M (SD) }\end{array}$ & $\begin{array}{l}\text { After experiment } \\
\text { M (SD) }\end{array}$ & $\begin{array}{l}\text { 95\% Cl for Mean } \\
\text { Difference }\end{array}$ & t value & Sig. & df \\
\hline $\begin{array}{l}\text { Without technology, without } \\
\text { what-if-not }\end{array}$ & 21 & $\begin{array}{c}2.41 \\
(0.81) \\
\end{array}$ & $\begin{array}{c}2.33 \\
(0.48) \\
\end{array}$ & $-0.43,0.53$ & 0.31 & 0.76 & 20 \\
\hline $\begin{array}{l}\text { Without technology, with } \\
\text { what-if-not }\end{array}$ & 20 & $\begin{array}{c}2.27 \\
(0.78) \\
\end{array}$ & $\begin{array}{c}4.05 \\
(1.19) \\
\end{array}$ & $-2.46,-1.10$ & -5.49 & 0.00 & 19 \\
\hline $\begin{array}{l}\text { With technology, without } \\
\text { what-if-not }\end{array}$ & 19 & $\begin{array}{r}2.38 \\
(0.83) \\
\end{array}$ & $\begin{array}{c}4.16 \\
(1.30) \\
\end{array}$ & $-2.5,-1.06$ & -5.17 & 0.00 & 18 \\
\hline $\begin{array}{l}\text { With technology, with what- } \\
\text { if-not }\end{array}$ & 19 & $\begin{array}{c}2.35 \\
(0.75) \\
\end{array}$ & $\begin{array}{c}7.11 \\
(0.81) \\
\end{array}$ & $-5.33,-4.18$ & -17.25 & 0.00 & 18 \\
\hline
\end{tabular}

Table 5. Means and standard deviations of students' flexibility with regard to strategies in the four groups

\begin{tabular}{|c|c|c|c|c|c|c|c|}
\hline Group & $\mathbf{N}$ & $\begin{array}{c}\text { Before experiment } \\
\text { M (SD) }\end{array}$ & $\begin{array}{l}\text { After experiment } \\
\text { M (SD) }\end{array}$ & $\begin{array}{l}\text { 95\% Cl for Mean } \\
\text { Difference }\end{array}$ & t value & Sig. & df \\
\hline $\begin{array}{l}\text { Without technology, without } \\
\text { what-if-not }\end{array}$ & 21 & $\begin{array}{l}1.98 \\
(0.63) \\
\end{array}$ & $\begin{array}{l}1.95 \\
(0.59) \\
\end{array}$ & $-0.34,0.39$ & 0.16 & 0.88 & 20 \\
\hline $\begin{array}{l}\text { Without technology, with } \\
\text { what-if-not }\end{array}$ & 20 & $\begin{array}{l}1.86 \\
(0.45) \\
\end{array}$ & $\begin{array}{l}2.00 \\
(0.46)\end{array}$ & $-0.44,0.16$ & -0.99 & 0.34 & 19 \\
\hline $\begin{array}{l}\text { With technology, without } \\
\text { what-if-not }\end{array}$ & 19 & $\begin{array}{l}1.85 \\
(0.79)\end{array}$ & $\begin{array}{l}2.32 \\
(0.48)\end{array}$ & $-0.95,0.1$ & -2.04 & 0.06 & 18 \\
\hline $\begin{array}{l}\text { With technology, with what- } \\
\text { if-not }\end{array}$ & 19 & $\begin{array}{c}1.88 \\
(0.76)\end{array}$ & $\begin{array}{c}2.89 \\
(0.32)\end{array}$ & $-1.46,-0.57$ & -4.78 & 0.00 & 18 \\
\hline
\end{tabular}

the angle and the pocket in which the ball falls? Describe the relationship between the table's dimensions, the angle's measure, and the pocket in which the ball falls?

Table 4 shows the mean scores and standard deviations of participants' flexibility concerning the types of problems in the four groups before and after the experiment, as well as t-value that compares the two means of each group.

The results of the paired-sample t-test showed significant differences between the mean scores of flexibility related to problem types, before and after the experiment, for the three experiment groups, but no significant difference was obtained for the control group $(p=0.76)$.

\section{Flexibility related to posing strategies before and after the use of tools}

As to the flexibility related to strategies, we identified four strategies used by the participants to pose problems: (a) posing problems about a specific mathematical object, without changing the problem's conditions, (b) posing problems about a specific mathematical object, changing the problem's conditions, (c) posing problems about a general mathematical object, and (d) posing problems about a mathematical relation. The four groups differed in their strategy use when posing problems. Both groups that did not use technology used at most two strategies: posing problems about a specific mathematical object, without changing the problem's conditions and posing problems about a specific mathematical object, changing the problem's conditions. The group that used technology but not the what-if-not strategy used at most two strategies: posing problems about a specific mathematical object, changing the problem's conditions, and posing problems about a general mathematical object. The group that used the combination of the tools used all the four strategies mentioned above.

Below are some examples of posed problems, chosen randomly from each of the categories in the order presented above. The problems were posed by the group that combined the two tools, where all the posing strategies appeared.

What is the difference between the geometric shape generated as a result of a ball hitting the sides of the $3 \times 4$ table and the geometric shape generated as a result of a ball hitting the sides of the $5 \times 6$ table? What is the number of ball hits for a $3 \times 5$ table if the number of pockets is four? What is the number of ball hits if table length is four times its width? What relationship is there between dimensions of the table and the number of ball hits when table length is odd and width is even?

Table 5 shows the mean scores and standard deviations of the participants' flexibility with regard to the different strategies in the four groups before and after the experiment, as well as $t$-value that compares the two mean scores of each group. 
Table 6. Means and standard deviations of students' originality in the four groups

\begin{tabular}{|c|c|c|c|c|c|c|c|}
\hline Group & $\mathbf{N}$ & $\begin{array}{c}\text { Before experiment } \\
M \text { (SD) }\end{array}$ & $\begin{array}{c}\text { After experiment } \\
M \text { (SD) }\end{array}$ & $\begin{array}{c}95 \% \mathrm{Cl} \text { for Mean } \\
\text { Difference }\end{array}$ & t value & Sig. & df \\
\hline $\begin{array}{l}\text { Without technology, without } \\
\text { what-if-not }\end{array}$ & 21 & $\begin{array}{l}0.17 \\
(0.51) \\
\end{array}$ & $\begin{array}{c}0.19 \\
(0.60) \\
\end{array}$ & $-0.43,0.38$ & -0.11 & 0.92 & 20 \\
\hline $\begin{array}{l}\text { Without technology, with } \\
\text { what-if-not }\end{array}$ & 20 & $\begin{array}{c}0.15 \\
(0.47) \\
\end{array}$ & $\begin{array}{c}0.10 \\
(0.31) \\
\end{array}$ & $-0.24,0.34$ & 0.37 & 0.72 & 19 \\
\hline $\begin{array}{l}\text { With technology, without } \\
\text { what-if-not }\end{array}$ & 19 & $\begin{array}{l}0.19 \\
(0.44) \\
\end{array}$ & $\begin{array}{c}0.68 \\
(0.75) \\
\end{array}$ & $-0.97,-0.07$ & -2.45 & 0.03 & 18 \\
\hline $\begin{array}{l}\text { With technology, with what- } \\
\text { if-not }\end{array}$ & 19 & $\begin{array}{c}0.16 \\
(0.49) \\
\end{array}$ & $\begin{array}{r}0.79 \\
(0.54) \\
\end{array}$ & $-0.95,-0.31$ & -4.10 & 0.00 & 18 \\
\hline
\end{tabular}

The above computations of the paired-sample t-test showed that there were significant differences between the two mean scores of flexibility-related-to-strategies, before and after the experiment, in the two experiment groups who used technology. No significant differences were obtained for the two groups who did not use technology $(p=0.88$ for the control group and $p=0.34$ for the group who used only what if not strategy).

\section{Originality in Problem Posing Before and After the Use of Tools}

We computed originality by calculating the number of problems posed only by a participant. We found two types of such problems: (a) those asking about an issue related to two of the following properties of the mathematical situation: dimensions, number of hits, hitting angle, and the number of corners, and (b) those asking about three of the mentioned properties. Below are some examples of problems posed (chosen from the problems posed by the research group that worked with what-if-not and with technology):

What angle measure should we use to obtain an equal number of hits for the two tables $2 \times 4$ and $3 \times 6$ ? How does the relationship between the number of ball hits and table dimensions change when we add four pockets to the table?

Table 6 shows the mean scores and standard deviations of the students' originality in the four groups before and after the experiment, as well as t-value that compares the two mean scores of each group.

The above computations of the paired-sample t-test showed that there were significant differences between the mean scores of the experiment groups who worked with technology, before and after the experiment. No significant differences were obtained for the groups who did not work with technology ( $p=0.92$ for the control group and $\mathrm{p}=0.72$ for the group who worked with the what-if-not strategy only).

The second research question asked whether the use of each of the tools and their combination in problem posing result in significant differences in the creativity scores among the four research groups. We answer this question for each creativity component.

\section{Differences in Fluency in Problem Posing between the Four Research Groups}

The results of the ANCOVA test (See Table 3 for the mean fluency scores of the four groups) showed that the mean fluency scores, after the experiment, differs significantly among the four groups, with $F(3,75)=60.72, p<0.01$, $\eta 2=0.71$. Cohen's standard states that the effect size is small if eta-squared is 0.02 . It is medium if eta-squared is 0.06 , and it is large if eta-squared is 0.14 (Cohen, 1988); therefore, the effect size we obtained is large.

The results of Scheffe post hoc test (See Table 7) showed that the mean fluency score of the group that used a combination of the tools was significantly higher than the other three groups $(p<0.01)$, whereas the mean fluency score of the group that did not use any of the tools was significantly lower than mean score of each of the other mean groups $(p<0.01)$. At the same time, the mean fluency scores of the two groups that used one tool only did not differ significantly $(\mathrm{p}=1.00)$. 
Table 7. Scheffe post hoc test for fluency

\begin{tabular}{|c|c|c|c|c|c|}
\hline Group (I) & Group (J) & Mean Difference (I-J) & Std. Error & Sig. & 95\% Confidence Interval of the Difference \\
\hline \multirow{3}{*}{1} & 2 & -3.53 & 0.74 & 0.00 & $-5.65,-1.42$ \\
\hline & 3 & -3.70 & 0.75 & 0.00 & $-5.84,-1.55$ \\
\hline & 4 & -9.96 & 0.75 & 0.00 & $-12.10,-7.82$ \\
\hline \multirow{3}{*}{2} & 1 & 3.53 & 0.74 & 0.00 & $1.42,5.65$ \\
\hline & 3 & -0.17 & 0.76 & 1.00 & $-2.33,2.00$ \\
\hline & 4 & -6.43 & 0.76 & 0.00 & $-8.60,-4.26$ \\
\hline \multirow{3}{*}{3} & 1 & 3.70 & 0.75 & 0.00 & $1.55,5.84$ \\
\hline & 2 & 0.17 & 0.76 & 1.00 & $-2.00,2.33$ \\
\hline & 4 & -6.26 & 0.77 & 0.00 & $-8.46,-4.07$ \\
\hline \multirow{3}{*}{4} & 1 & 9.96 & 0.75 & 0.00 & $7.82,12.10$ \\
\hline & 2 & 6.43 & 0.76 & 0.00 & $4.26,8.60$ \\
\hline & 3 & 6.26 & 0.77 & 0.00 & $4.07,8.46$ \\
\hline
\end{tabular}

Group 1: Without technology, without what-if-not, group 2: Without technology, with what-if-not, group 3: With technology, without what-if-not, group 4: With technology, with what-if-not

Table 8. Scheffe post hoc test for flexibility of problem types

\begin{tabular}{|c|c|c|c|c|c|}
\hline Group (I) & Group (J) & Mean Difference (I-J) & Std. Error & Sig. & 95\% Confidence Interval of the Difference \\
\hline \multirow{3}{*}{1} & 2 & -1.72 & 0.31 & 0.00 & $-2.60,-0.83$ \\
\hline & 3 & -1.83 & 0.31 & 0.00 & $-2.72,-0.93$ \\
\hline & 4 & -4.77 & 0.31 & 0.00 & $-5.67,-3.87$ \\
\hline \multirow{3}{*}{2} & 1 & 1.72 & 0.31 & 0.00 & $0.83,2.60$ \\
\hline & 3 & -0.11 & 0.32 & 0.99 & $-1.02,0.80$ \\
\hline & 4 & -3.06 & 0.32 & 0.00 & $-3.96,-2.15$ \\
\hline \multirow{3}{*}{3} & 1 & 1.83 & 0.31 & 0.00 & $0.93,2.72$ \\
\hline & 2 & 0.11 & 0.32 & 0.99 & $-0.80,1.02$ \\
\hline & 4 & -2.95 & 0.32 & 0.00 & $-3.87,-2.03$ \\
\hline \multirow{3}{*}{4} & 1 & 4.77 & 0.31 & 0.00 & $3.87,5.67$ \\
\hline & 2 & 3.06 & 0.32 & 0.00 & $2.15,3.96$ \\
\hline & 3 & 2.95 & 0.32 & 0.00 & $2.03,3.87$ \\
\hline
\end{tabular}

Group 1: Without technology, without what-if-not, group 2: Without technology, with what-if-not, group 3: With technology, without what-if-not, group 4: With technology, with what-if-not

\section{Differences in Flexibility in Problem Posing between the Four Research Groups}

\section{Differences in flexibility related to problem types between the four research groups}

As to differences in flexibility in problem types (See Table 4 for the mean flexibility related to types scores of the four groups), the results of the ANCOVA test showed that the mean score of flexibility related to problem types was significantly different among the four groups, with $\mathrm{F}(3,75)=77.60, \mathrm{p}<0.01, \mathrm{\eta} 2=0.76$. Cohen's standard indicates that the effect size is large. The Scheffe post hoc test (See Table 8) showed that the mean score of flexibility related to problem types of the group who combined the two tools was significantly higher than that of the other three groups ( $\mathrm{p}<0.01$ ), and that the mean score of the group that did not use any tool was significantly lower than that of each of the other groups ( $p<0.01$ ). At the same time, the mean scores of flexibility related to problem types of the two groups that used one tool alone was not significantly different $(p=0.99)$.

\section{Differences in flexibility related to strategies between the four research groups}

As to differences in flexibility in problem strategies (See Table 5 for the mean flexibility related to strategies scores of the four groups), the results of the ANCOVA test showed that the mean score of flexibility regarding strategies differed significantly among the four research groups, with $F(3,75)=16.11, p<0.01, \eta 2=0.40$. Cohen's standard indicates that the effect size is large. The results of Scheffe post hoc test (See Table 9) showed that the mean score of flexibility related to strategies of group that used a combination of the tools was significantly higher than the mean score of the other three groups $(p<0.01)$. At the same time, no significant difference we found between the mean scores of flexibility related to strategies among the other three research groups. 
Table 9. Scheffe post hoc test for flexibility of problem strategies

\begin{tabular}{|c|c|c|c|c|c|}
\hline Group (I) & Group (J) & Mean Difference (I-J) & Std. Error & Sig. & 95\% Confidence Interval of the Difference \\
\hline \multirow{3}{*}{1} & 2 & -0.05 & 0.15 & 0.99 & $-0.47,0.38$ \\
\hline & 3 & -0.36 & 0.15 & 0.13 & $-0.79,0.07$ \\
\hline & 4 & -0.94 & 0.15 & 0.00 & $-1.37,-0.51$ \\
\hline \multirow{3}{*}{2} & 1 & 0.05 & 0.15 & 0.99 & $-0.38,0.47$ \\
\hline & 3 & -0.32 & 0.15 & 0.24 & $-0.75,0.12$ \\
\hline & 4 & -0.90 & 0.15 & 0.00 & $-1.33,-0.46$ \\
\hline \multirow{3}{*}{3} & 1 & 0.36 & 0.15 & 0.13 & $-0.07,0.79$ \\
\hline & 2 & 0.32 & 0.15 & 0.24 & $-0.12,0.75$ \\
\hline & 4 & -0.58 & 0.15 & 0.00 & $-1.02,-0.14$ \\
\hline \multirow{3}{*}{4} & 1 & 0.94 & 0.15 & 0.00 & $0.51,1.37$ \\
\hline & 2 & 0.90 & 0.15 & 0.00 & $0.46,1.33$ \\
\hline & 3 & 0.58 & 0.15 & 0.00 & $0.14,1.02$ \\
\hline
\end{tabular}

Group 1: Without technology, without what-if-not, group 2: Without technology, with what-if-not, group 3: With technology, without what-if-not group 4: With technology, with what-if-not

Table 10. Scheffe post hoc test for originality

\begin{tabular}{|c|c|c|c|c|c|}
\hline Group (I) & Group (J) & Mean Difference (I-J) & Std. Error & Sig. & 95\% Confidence Interval of the Difference \\
\hline \multirow{3}{*}{1} & 2 & 0.09 & 0.18 & 0.97 & $-0.42,0.60$ \\
\hline & 3 & -0.49 & 0.18 & 0.07 & $-1.01,0.02$ \\
\hline & 4 & -0.60 & 0.18 & 0.02 & $-1.11,-0.08$ \\
\hline \multirow{3}{*}{2} & 1 & -0.09 & 0.18 & 0.97 & $-0.60,0.42$ \\
\hline & 3 & -0.58 & 0.18 & 0.02 & $-1.11,-0.06$ \\
\hline & 4 & -0.70 & 0.18 & 0.00 & $-1.21,-0.17$ \\
\hline \multirow{3}{*}{3} & 1 & 0.49 & 0.18 & 0.07 & $-0.02,1.01$ \\
\hline & 2 & 0.58 & 0.18 & 0.02 & $0.06,1.11$ \\
\hline & 4 & -0.11 & 0.19 & 0.96 & $-0.63,0.42$ \\
\hline \multirow{3}{*}{4} & 1 & 0.60 & 0.18 & 0.02 & $0.08,1.11$ \\
\hline & 2 & 0.70 & 0.18 & 0.00 & $0.17,1.21$ \\
\hline & 3 & 0.11 & 0.19 & 0.96 & $-0.42,0.63$ \\
\hline
\end{tabular}

Group 1: Without technology, without what-if-not, group 2: Without technology, with what-if-not, group 3: With technology, without what-if-not group 4: With technology, with what-if-not

\section{Differences in Originality in Problem Posing between the Four Research Groups}

The results of the ANCOVA test (See Table 6 for the mean originality scores of the four groups) showed that the mean score of originality differs significantly among the four research groups, with $F(3,75)=7.22, p<0.01, \eta 2$ $==0.23$. Cohen's standard indicates that the effect size is large. The results of Scheffe post hoc test (See Table 10) showed that the mean score of originality of pre-service teachers who worked with technology, whether with or without the what-if-not strategy, are higher than the originality score of the groups who worked without it ( $p$ $<0.01)$.

\section{DISCUSSION}

Pre-service teachers, in their instruction in the mathematics classes, bring significant mathematical and pedagogical knowledge, especially to their problem posing activity (Ellerton, 2013). How could tools affect this problem posing activity? In the current research, we examined whether pre-service teachers' use of tools, specifically technology and what-if-not strategy, impacted their creativity in problem posing. To do so, we explored, following other researchers (e.g., Kattou, Kontoyianni, Pitta-Pantazi, \& Christou, 2013; Silver, 1997; Sriraman et al., 2013) three creativity components: fluency, flexibility, and originality. As reported in previous studies (Behzadi \& Manuchehri, 2013; NACCCE, 1999; Sophocleous \& Pitta-Pantazi, 2011), the present research results indicate that technology supported the creativity of pre-service teachers in the problem posing activity (Abramovich \& Cho, 2006; Christou, Mousoulides, Pittalis, \& Pitta-Pantazi, 2005). At the same time, the what-ifnot strategy also enriched the problem-posing activity of the pre-service teachers (Brown \& Walter, 1990, 1993; Silver, 1994), and generally in their creativity (Shriki, 2013; Silver, 1997). Nevertheless, in the present research, the what-if-not strategy did not support the pre-service teachers in their flexibility related to posing strategies or originality, probably because the what-if-not strategy has the potentiality to put the learner's problem-posing activity on an exact track, which limits the use of posing strategies and their use of novel ideas. This use of novel 
ideas is linked to originality (e.g., Levenson, 2011; Nadjafikhah, Yaftian, \& Bakhshalizadeh, 2012), so what-if-not strategy did not influence significantly the participants' originality too.

More specifically, the research findings indicate that the four participating groups differed significantly in their mean score of fluency. The group of pre-service teachers, who achieved the highest mean score, was the one that used a combination of the tools, whereas the group of pre-service teachers, who did not use any tool, achieved the lowest mean score. These results indicate the contribution of both tools to learners' problem posing. The positive effect of the what-if-not strategy was probably due to the fact that it is a tool for organizing the work in problemposing activities (Christou et al., 2005). This organization is explicit in the specific procedure of the what-if-not strategy, where it starts with stating the givens of the problem, and continues with negating them and examining what results from this negation. At the same time, the positive effect of technology on pre-service teachers' fluency in problem posing was probably due to the dynamic affordances of technology (Lagrange, Artigue, Laborde, \& Trouche, 2003; Sinclair, 2004), which encourage students' exploration of the mathematical phenomena or topic. In our case, the java applet facilitated the participants' actions of changing the table dimensions and ball speed, counting the number of hits, and showing the path of the ball. It is reasonable to argue that the applet made participants aware of the problem situation (Lombardi, 2007; Pea, 1987), in our case the problem conditions, in the same way that the what-if-not strategy did. Such awareness helped the participants pose more problems by manipulating the applet's sliders or options and thus changing the mathematical situation's conditions. Observing the results of the change supported the participants to pose more problems. These results are consistent with Lavy and Shriki (2010), who found that students working in a computerized problem-posing setting believed that their activity enriched both their mathematical content knowledge and their meta-mathematical knowledge.

We considered two types of pre-service teachers' flexibility. The first was concerned with the types of problems, while the second was concerned with the strategies used (see, for example, Kontorovich et al., 2011). The findings concerning the flexibility in types of problems are similar to those concerning fluency. In this case as well, the whatif-not strategy and technology helped organize and situate pre-services teachers' problem posing, making the participants aware of the different components of the mathematical situation and thus helping them pose problems about each these components.

Regarding flexibility in the use of strategies, technology affected positively and significantly this flexibility, while the what-if-not strategy did not. Watching different examples, while utilizing technology, helped the preservice teachers pay attention to generalizations (Bransford, Brown, \& Cocking, 2000) related to the mathematical situation, and pose problems about these generalizations. The ability to observe different examples with the help of software (the Java applet) served as a generic organizer or reorganizer of the mathematical situation (Goos, Galbraith, Renshaw, \& Geiger, 2003; Pea, 1987; Tall, 1989, 2002), encouraging the pre-service teachers to use more creative strategies in posing mathematical problems related to the given situation. The inability of the what-if-not strategy to better students' flexibility-related-to-strategies is a result of the strategy leading the students in a predefined way to pose problems, which constrained their use of different posing strategies.

The findings of the present research also showed that the group who combined the tools showed significantly higher flexibility related-to-strategies than the three other groups. Thus, the combination of the couple of tools helped the participants use different strategies more than did either technology or the what-if-not strategy alone. This effect is probably a result of the explorative systemic variation with which pre-service teachers changed the conditions of the mathematical situation and which was facilitated by the utilization of what-if-not strategy (Silver, 1994). This utilization directed the attention of the pre-service teachers to the possibility of changing the conditions of mathematical situation systematically and encouraged them to pose problems about each of them. At the same time, the presence of technology encouraged the pre-service teachers' exploration and imagination of the different possibilities of changing the conditions, which gave rise to different posing strategies. These technology capabilities are reported in the literature, for example Sinclair (2004) pointed out that technology provides dragging functionality that enables learners to use visual reasoning and to make generalizations for problems and relationships (Sinclair, 2004).

The findings of the current research indicated that the originality of pre-service teachers who worked without technology but with a what-if-not strategy was significantly lower than that of pre-service teachers who worked with technology, whether without or with the what-if-not strategy. These findings agree with researchers' claim that technology can be a facilitator of students' creativity (e.g., Yerushalmy, 2009). These results can be explained in the same way as the results concerning the participants' flexibility in posing strategies, where the features and potentialities of technology helped them gain awareness of the different conditions of the situation, resulting in awareness of conditions not stated directly in the problem, such as the shape of the table. Furthermore, these results indicate that technology that enables dynamic investigation of mathematical ideas gives open space for students to think creatively more than tools which encourage their systemic thinking.

Kontorovich et al. (2011) found it difficult to measure the originality component of creativity because in no instances did two posed problems match. This was not the case in our design, where the posed problems did match, 
especially with the participants who worked with technology. This difference between the way in which the two studies measured originality is due to the different contexts in which the participating pre-service teachers worked: in groups, in Kontorovich et al. (2011), and individually, in the present study. Researchers have long emphasized the effect of context on students' learning, and especially creativity (e.g., Sriraman et al., 2013; Voica, \& Singer, 2013). Voica and Singer say that problem-posing sessions constitute a simple context in which students can generate structured knowledge. Moreover, Sriraman et al. (2013) argue that novelty rests on the setting of the creative process of the learner. In addition, Amabile $(1983,1999)$ described the effect of social variables on motivational orientation toward creativity in general. These social variables, in our case the tools used by participants, whether they were technological or learning/teaching strategies, affected their mathematical problem posing activity, and specifically their creativity in this problem posing.

The current study followed other previous researches in mathematics education to investigate three components of creativity; i.e. fluency, flexibility and originality. Future research would study how the tools impact other components of mathematical creativity, as elaboration that has been little studied in previous mathematic education research, though it has been mentioned in some studies as one component of creativity (e.g., Kanematsu \& Barry, 2016; Leikin \& Lev, 2013). Furthermore, the present study investigated how tools and combination between them affect students' creativity in problem posing. Future research is needed to study this issue for other tools. It is also interesting to study the difference of students' creativity when using different tools, for example physical and virtual manipulatives.

\section{CONCLUSIONS}

Researchers in mathematics education emphasize the role of creativity in the mathematics classroom. Sarrazy and Novotna (2013) consider the ability of students to produce original solutions to new problems as one of the indicators of learning and one way that serves the teacher to assess students' conceiving of the taught mathematical concepts and relations. This implies that nourishing creativity in mathematics education is of paramount importance. Mann (2005) pointed at the need for time for creativity to develop through experience, and Silver (1997) maintained that creativity is enriched with continuous work and reflection, and is affected by instructional and experiential influences. It is therefore necessary to carefully plan the nurturing of creativity in the mathematics classroom (Palha, Schuitema, van Boxtel, \& Peetsma, 2015). In the present study, we attempted to do so through problem posing which is connected to creative activity that can be sustained in structured contexts that combine between real-life artefacts and human interactions (Bonotto, 2013). The contexts in which the participants worked included technology and what-if-not strategy, while the real-life artefacts included the Paper Pool situation. We examined whether these contexts nourish the creativity of pre-service teachers in problem posing. The research results indicate that technology fosters the three types of mathematical creativity in the mathematics classroom, while the what-if-not strategy fosters fluency and flexibility-related-to-problems. These influences can be related to the tools serving to organize the investigation of mathematical ideas (Tall, 1989, 2002) and technology supporting the imagination of alternatives to the mathematical situation. Specifically, technology turns the problem-posing activity into a dynamic and an interactive one, in which students interact with a given system to conceive knowledge. The interactive environment had a positive effect on pre-service teachers' activity (Scherer \& Tiemann, 2014), in our case, problem posing (Abu-Elwan, 2011).

Our results showed that the technology tool is more effective than the what-if-not strategy tool in encouraging flexibility-related-to-strategies and originality in problem posing, by enabling the participants to observe the mathematical situation and actively explore it (Lagrange \& Artigue, 2009). This active observation and exploration of the mathematical situation helps the students in their mathematical learning (Lagrange et al., 2003; Zales, 1997), including their problem solving and posing. This explanation clarifies our results concerning the effective influence of technology on the participants' problem posing.

We recommend the use of technology together with the what-if-not strategy in order to enhance pre-service teachers' mathematical thinking, because this combination makes available for student's learning multiple agencies required for his/ her creative acts (Sinclair, de Freitas \& Ferrara, 2013).

\section{REFERENCES}

Abramovich, S., \& Cho, E. (2006). Technology as a Medium for Elementary Preteachers' Problem-Posing Experience in Mathematics. Journal of Computers in Mathematics and Science Teaching, 25(4), 309-323.

Abramovich, S., \& Cho, E. (2015). Using digital technology for mathematical problem posing, in: F. M. Singer, N. Ellerton, \& J. Cai (Eds), Mathematical problem posing: From research to effective practice (pp. 71-102), New York: Springer. https:/ / doi.org/10.1007/978-1-4614-6258-3_4 
Abu-Elwan, R. (2011). How prospective teachers' use of the Cabri II environment can have an effect on the posing of fractal problems In M. Joubert, A. Clark-Wilson, \& M. McCabe (eds.), The 10th International Conference on Technology in Mathematics Teaching (pp. 56-61). Portsmouth, UK: University of Portsmouth.

Akay, H., \& Boz, N. (2009). Prospective teachers' views about problem-posing activities. Procedia Social and Behavior Sciences, 1(1), 1192-1198. https:// doi.org/10.1016/j.sbspro.2009.01.215

Amabile, T. M. (1983). The social psychology of creativity. New York: Springer-Verlag. https://doi.org/10.1007/978$1-4612-5533-8$

Amabile, T. M. (1999). How to kill creativity. Harvard Business Review, 76(5), 76-87.

Beal, C. R., \& Cohen, P. R. (2012). Teach Ourselves: Technology to Support Problem Posing in the STEM Classroom. Creative Education, 3(4), 513-519. https:// doi.org/10.4236/ce.2012.34078

Behzadi, M., \& Manuchehri, M. (2013). Examining creativity of students through smart board in learning mathematics. Mathematics Education Trends and Research, 1, 1-7. Retrieved from http:/ / www.ispacs.com/journals/metr/2013/metr-00008/article.pdf https:/ / doi.org/10.5899/2013/metr-00008

Bolden, D., Harries, A., \& Newton, D. (2010). Pre-service primary teachers' conceptions of creativity in mathematics. Educational Studies in Mathematics, 73 (2), 143-157. https: / / doi.org/10.1007/s10649-009-9207-z

Bonotto, C. (2013). Artifacts as sources for problem-posing activities. Educational Studies in Mathematics, 83(1), 3755. https:/ / doi.org/10.1007/s10649-012-9441-7

Bransford, J. D., Brown, A. L., \& Cocking, R. R. (2000). How people learn: Brain, mind, experience, and school. Washington, D.C.: National Academy Press.

Brown, S. I., \& Walter, I. (1990). The art of problem posing (2nd ed.). Hillsdale, NJ: Lawrence Erlbaum Associates.

Brown, S. I., \& Walter, M. I. (1969). What if not? Mathematics Teaching, 46, 38-45.

Brown, S. I., \& Walter, M. I. (1993). Problem posing in mathematics education. In S. I. Brown \& M. I. Walter (Eds.), Problem posing: Reflections and application (pp. 16-27). Hillsdale, NJ: Lawrence Erlbaum Associates.

Buteau, C. (2008). Triggering university students' mathematical creativity and intellectual independence by use of technology: une implémentation à brock university. Paper presented at the Deuxième Congrès Canada-France Université du Québec à Montréal, 2 au 5 Juin 2008.

Christou, C. (2005). Problem solving and problem posing in a dynamic geometry environment. The Montana Mathematics Enthusiast, 2(2), 125-143.

Christou, C., Mousoulides, N., Pittalis, M., \& Pitta-Pantazi, D. (2005). Problem Solving and Problem Posing in a Dynamic Geometry Environment. The Mathematics Enthusiast, 2(2). http:/ / scholarworks.umt.edu/tme/vol2/iss2/6

Clements, D. H. (1995). Teaching creativity with computers. Educational Psychology Review, 7(2), 141-161. https:/ / doi.org/10.1007/BF02212491

Cohen, J. (1960) A coefficient of agreement for nominal scales. Educational and Psychological Measurement, 20, 37-46. https:/ / doi.org/10.1177/001316446002000104

Cohen, J. (1988). Statistical power analysis for the behavioral sciences (2nd ed.). Hillsdale, NJ: Lawrence Earlbaum Associates.

Dunham, P., \& Dick, T. (1994). Research on graphing calculators. Mathematics Teacher, 87, 440-445.

Ellerton, N. F. (2013). Engaging pre-service middle-school teacher-education students in mathematical problem posing: Development of an active learning framework. Educational Studies in Mathematics, 83(1), 87-101. https:/ / doi.org/10.1007/s10649-012-9449-z

English, L. D. (2009). The changing realities of classroom mathematical problem solving. In L. Verschaffel, B. Greer, W. Van Dooren, \& S. Mukhopadhyay (Eds.), Words and worlds: Modelling verbal descriptions of situations (pp. 351-362). Rotterdam: Sense Publishers.

English, L. N. (1998). Children's problem posing within formal and informal contexts. Journal for Research in Mathematics Education, 29(1), 83-107. https:/ / doi.org/10.2307/749719

Freudenthal, H. (1991). Revisiting mathematics education. China lectures. Dordrecht: Kluwer.

Goos, M., Galbraith, P., Renshaw, P., \& Geiger, V. (2003). Perspectives on technology mediated learning in secondary school mathematics classrooms. The Journal of Mathematical Behavior, 22(1), 73-89. https:/ / doi.org/10.1016/S0732-3123(03)00005-1

Guilford, J. P. (1950). Creativity. American Psychologist, 5, 444-454. https:/ / doi.org/10.1037/h0063487 
Guilford, J. P. (1975). Creativity: A quarter century of progress. In I. A.Taylor \& J. W. Getzels (Eds.), Perspectives in creativity (pp. 37-59). Chicago: Aldine.

Haylock, D. (1987). A framework for assessing mathematical creativity in school children. Educational Studies in Mathematics, 18(1), 59-74. https://doi.org/10.1007/BF00367914

Hoyles, C. (2001). Steering between skills and creativity: A role for the computer? For the Learning of Mathematics, 21, 33-39.

James, V., Lederman, G. R., \& Vagt-Traore, B. (2010). Enhancing creativity in the classroom. In M. Orey (Ed.), Emerging perspectives on learning, teaching, and technology (pp. 104-114). Zurich, Switzerland: Jacobs Foundation.

Kanematsu, H., \& Barry, D.M. (2016). STEM and ICT education in intelligent environments. Cham, Switzerland: Springer. https:// doi.org/10.1007/978-3-319-19234-5

Kattou, M., Kontoyianni, K., Pitta-Pantazi, D., \& Christou, C. (2013). Connecting mathematical creativity to mathematical ability. ZDM, 45(2), 167-181. https:/ / doi.org/10.1007/s11858-012-0467-1

Kilic, C. (2013). Pre-service primary teachers' free problem-posing performances in the context of fractions: An example from Turkey. The Asia-Pacific Education Researcher, 22(4), 677-686. https:/ / doi.org/10.1007/s40299013-0073-1

Kilpatrick, J. (1987). Problem formulating: Where do good problems come from? In A. H. Schoenfeld (Ed.), Cognitive science and mathematics education (pp. 123-147). Hillsdale: Lawrence Erlbaum Associates.

Koichu, B., \& Kontorovich, I. (2013). Dissecting success stories on mathematical problem posing: A case of the billiard task. Educational Studies in Mathematics, 83(1), 71-86. https:// doi.org/10.1007/s10649-012-9431-9

Kontorovich, I., Koichu, B., Leikin, R., \& Berman, A. (2011). Indicators of creativity in mathematical problem posing: How indicative are they? In M. Avotina, D. Bonka, H. Meissner, L. Ramāna, L. Sheffield \& E. Velikova (Eds.), Proceedings of the 6th International Conference Creativity in Mathematics Education and the Education of Gifted Students (pp. 120-125). Latvia: Latvia University.

Lagrange, J.-B., \& Artigue, M. (2009). Students' activities about functions at upper secondary level: a grid for designing a digital environment and analysing uses. In M. Tzekaki, M. Kaldrimidou \& C. Sakonidis (Eds.), Proceedings of the 33rd Conference of the International Group for the Psychology of Mathematics Education (Vol. 3, pp. 465-472). Thessaloniki, Greece: PME.

Lagrange, J.-B., Artigue, M., Laborde, C., \& Trouche, L. (2003). Technology and Mathematics Education: A Multidimensional Study of the Evolution of Research and Innovation. In A. Bishop, M.A. Clements, C. Keitel-Kreidt, J. Kilpatrick, \& F.K.-S. Leung (eds.), Second International handbook of research in mathematics education (pp.239-271). Dordrecht: Kluwer Academic Publishers. https:/ / doi.org/10.1007/978-94-010-02738_9

Lai, E. R. (2011). Critical thinking: A literature review. http://www.pearsonassessments.com/hai/images/tmrs/CriticalThinkingReviewFINAL.pdf

Lavy, I., \& Bershadsky, I. (2003). Problem Posing via “What if not?" strategy in Solid Geometry - A Case Study. The Journal of Mathematical Behavior, 22(4) 369-387. https:/ / doi.org/10.1016/j.jmathb.2003.09.007

Lavy, I., \& Shriki, A. (2010). Engaging in problem posing activities in a dynamic geometry setting and the development of prospective teachers' mathematical knowledge. The Journal of Mathematical Behavior, 29(1), 11-24. https://doi.org/10.1016/j.jmathb.2009.12.002

Leikin, R., \& Lev, M. (2013). Mathematical creativity in generally gifted and mathematically excelling adolescents: what makes the difference? ZDM, 45(2), 183-197. https://doi.org/10.1007/s11858-012-0460-8

Leikin, R., \& Pitta-Pantazi, D. (2013). Creativity and mathematics education: the state of the art. ZDM, 45(2), 159166. https:// doi.org/10.1007/s11858-012-0459-1

Leikin, R., Koichu, B., \& Berman, A. (2009). Mathematical giftedness as a quality of problem-solving acts. In R. Leikin, A. Berman, \& B. Koichu (Eds.), Creativity in mathematics and the education of gifted students (pp. 115128). Rotterdam: Sense Publishers.

Leung, S. S. (2013). Teachers implementing mathematical problem posing in the classroom: Challenges and strategies. Educational Studies in Mathematics, 83(1), 103-116. https:/ / doi.org/10.1007/s10649-012-9436-4

Levenson, E. (2011). (Naïve) beliefs and affect associated with creative mathematical tasks: Three cases. In B. Rösken \& M. Casper (Eds.), current state of research on mathematical beliefs XVII: Proceedings of the MAVI-17 Conference (pp. 140-149). Bochum, Germany: MAVI.

Liekin, R. (2011). The education of mathematically gifted students: Some complexities and questions. The Mathematics Enthusiast, 8(1\&2), 167-188. 
Lombardi, M. M. (2007). Authentic learning for the 21st century: An overview. Educause Learning Initiative. https:// net.educause.edu/ir/library/pdf/ELI3009.pdf

Mamona-Downs, J., \& Downs, M. (2005). The identity of problem solving. The Journal of Mathematical Behavior, 24, 385-401. https:// doi.org/10.1016/j.jmathb.2005.09.011

Mann, E. (2005). Mathematical Creativity and School Mathematics: Indicators of Mathematical Creativity in Middle School Students (Unpublished doctoral dissertation). University of Connecticut, Connecticut, US.

Mann, E. L. (2006). Creativity: The essence of mathematics. Journal for the Education of the Gifted, 30(2), 236-260. https:// doi.org/10.4219/jeg-2006-264

Nadjafikhah, M., Yaftian, N., \& Bakhshalizadeh, S. (2012). Mathematical creativity: some definitions and characteristics. Procedia-Social and Behavioral Sciences, 31, 285-291. https:/ / doi.org/10.1016/j.sbspro.2011.12.056

National Advisory Committee on Creative and Cultural Education (NACCCE) (1999). All our futures: Creativity, culture and education. London, UK: DFES.

National Council of Teachers of Mathematics (NCTM) (2000). Principles and standards for school mathematics. Reston, VA: Author.

Palha, S., Schuitema, J., van Boxtel, C., \& Peetsma, T. (2015). The effect of high versus low guidance structured tasks on mathematical creativity. In K. Krainer, \& N. Vondrová (eds.), Proceedings of the Ninth Congress of the European Society for Research in Mathematics Education (pp.1039-1045). Prague, Czech Republic: ERME.

Pásztor, A., Molnár, G., \& Csapó, B. (2015). Technology-based assessment of creativity in educational context: the case of divergent thinking and its relation to mathematical achievement. Thinking Skills and Creativity, 18, 3242. https:/ / doi.org/10.1016/j.tsc.2015.05.004

Pea, R. D. (1987). Cognitive technologies in mathematics education. In A. H. Schoenfeld (Ed.), Cognitive science and mathematics education (pp. 89-122). Hilldale, NJ: Erlbaum.

Sarrazy, B., \& Novotna, J. (2013). Didactical contract and responsiveness to didactical contract: a theoretical framework for enquiry into students' creativity in mathematics. ZDM, 45(2), 281-293. https:/ / doi.org/10.1007/s11858-013-0496-4

Scherer, R., \& Tiemann, R. (2014). Evidence on the effects of task interactivity and grade level on thinking skills involved in complex problem solving. Thinking Skills and Creativity, 11, 48-64. https:/ / doi.org/10.1016/j.tsc.2013.10.003

Shriki, A. (2013). A model for assessing the development of students' creativity in the context of problem posing. Creative Education, 4(7), 430-439. https:/ / doi.org/10.4236/ce.2013.47062

Silver, E. A. (1994). On mathematical problem posing. For the Learning of Mathematics, 14, 19-28.

Silver, E. A. (1997). Fostering creativity through instruction rich in mathematical problem solving and problem posing. ZDM, 3, 75-80. https://doi.org/10.1007/s11858-997-0003-x

Silver, E. A., \& Cai, J. (2005). Assessing students' mathematical problem posing. Teaching Children Mathematics, 12(3), 129-135.

Silver, E. A., Mamona-Downs, J., Leung, S., \& Kenny, P. A. (1996). Posing mathematical problems: an exploratory study. Journal for Research in Mathematics Education, 27(3), 293-309. https:/ / doi.org/10.2307/749366

Sinclair, N. (2004). The roles of the aesthetic in mathematical inquiry. Mathematical Thinking and Learning, 6(3), 261284. https://doi.org/10.1207/s15327833mt10603_1

Sinclair, N., de Freitas, E., \& Ferrara, F. (2013). Virtual encounters: the murky and furtive world of mathematical inventiveness. ZDM, 45(2), 239-252. https://doi.org/10.1007/s11858-012-0465-3

Singer, F. M., Ellerton, N., \& Cai, J. (2013). Problem posing research in mathematics education: new questions and directions. Education Studies in Mathematics, 83(1), 1-7. https:/ / doi.org/10.1007/s10649-013-9478-2

Sophocleous, P., \& Pitta-Pantazi, D. (2011). Creativity in three-dimensional geometry: How an interactive 3Dgeometry software environment enhance it? In M. Pytlak, T. Rowland, \& E. Swoboda (Eds.), Proceedings of Seventh Conference of the European Research in Mathematics Education (pp. 1143 - 1153). Rzeshów, Poland: ERME.

Sriraman, B. (2005). Are giftedness and creativity synonyms in mathematics? Prufrock Journal, 17(1), 20-36. https:// doi.org/10.4219/jsge-2005-389

Sriraman, B., Haavold, P., \& Lee, K. (2013). Mathematical creativity and giftedness: a commentary on and review of theory, new operational views, and ways forward. ZDM, 45(2), 215-225. https:/ / doi.org/10.1007/s11858013-0494-6 
Sternberg, R. J., \& Lubart, T. I. (1999). The concept of creativity: Prospects and paradigms. In R. J. Sternberg (Ed.), Handbook of creativity (pp. 3-15). Cambridge: Cambridge University Press.

Stoyanova, E. (1998). Problem posing in mathematics classrooms. In A. McIntosh \& N. Ellerton (Eds.), Research in mathematics education: a contemporary perspective (pp. 164 - 185). Edith Cowan University: MASTEC.

Subhi, T. (1999). The impact of logo on gifted children's achievement and creativity. Journal of Computer Assisted Learning, 15(2), 98-108. https:/ / doi.org/10.1046/j.1365-2729.1999.152082.x

Tall, D. O. (1989). Concept images, generic organizers, computers \& curriculum change. For the Learning of Mathematics, 9(3), 37-42.

Tall, D. O. (2002). Using technology to support an embodied approach to learning concepts in mathematics. Paper presented at First Coloquio do Historia e Tecnologia no Ensino de Matematica at Universidade do Estado do Rio De Janiero, February 21-3, 2002.

Torrance, E. P. (1966). The Torrance tests of creative thinking-norms-technical manual research edition-verbal tests, forms A and B-figural tests, forms $A$ and B. Princeton, NJ: Personnel Press.

Torrance, E. P. (1969). Creativity. What research says to the teacher. Washington, DC: National Education Association.

Torrance, E. P. (1974). Torrance tests of creative thinking: Norms-technical manual. Bensenville, IL: Scholastic Testing Service.

Voica, C., \& Singer, F. M. (2013). Problem modification as a tool for detecting cognitive flexibility in school children. ZDM, 45(2), 267-279. https:/ / doi.org/10.1007/s11858-013-0492-8

Wood, R., \& Ashfield, J. (2008). The use of the interactive whiteboard for creative teaching and learning in literacy and mathematics: a case study. British Journal of Educational Technology, 39(1), 84-96. https://doi.org/10.1111/j.1467-8535.2007.00699.x

Yerushalmy, M. (2009). Educational technology and curricular design: Promoting mathematical creativity for all students. In R. Leikin, A. Berman \& B. Koichu (Eds.), Mathematical creativity and the education of gifted students (pp. 101-113). Rotterdam, The Netherlands: Sense Publishers.

Zales, C. R. (1997). Improving student achievement in mathematics through active learning. Center Valley, Pennsylvania: Allentown College of St. Francis de Sales.

\section{http://www.ejmste.com}

